Cahiers d'études italiennes

18 | 2014

NOVECENTO... E DINTORNI

Da Torino a Parigi: Laura Malvano storica e critica d'arte

\title{
The Radiant Child
}

L'Enfant radieux

Il Fanciullo radioso

John Bentley Mays

\section{(2) OpenEdition}

\section{Journals}

Electronic version

URL: http://journals.openedition.org/cei/1862

DOI: $10.4000 /$ cei. 1862

ISSN: 2260-779X

\section{Publisher}

UGA Éditions/Université Grenoble Alpes

\section{Printed version}

Date of publication: 30 March 2014

Number of pages: $187-197$

ISBN: 978-2-84310-268-4

ISSN: 1770-9571

\section{Electronic reference}

John Bentley Mays, "The Radiant Child", Cahiers d'études italiennes [Online], 18| 2014, Online since 30

September 2015, connection on 26 March 2021. URL: http://journals.openedition.org/cei/1862 ; DOI: https://doi.org/10.4000/cei.1862 


\title{
THE RADIANT CHILD
}

\author{
John Bentley Mays
}

Of all the preoccupations that haunt modern imagination in the West, none is more complex or more sheerly interesting than the fascination with immaturity, whether of the person (childhood and adolescence) or of civilization itself. This enthrallment comes and goes, but never disappears, and it seems lodged in the basic structures of our cultural consciousness. Since the Enlightenment until the present day, Western adults have either cherished or dreaded, admired or shunned or regarded with powerful, vexed curiosity those persons or peoples categorized as "young", "primitive", "unformed"-but nobody has ever ignored them.

Indeed, Westerners have tended to idealize them, make them exemplary. Nothing is more obviously true to the modern mind, for example, than the relatively recent proposition that children (and, by familiar extension, pre-urbanized or "tribal" societies) are innocent and ebullient until spoiled by adulthood and "civilization". Nor have the contrary findings of psychologists and ethnologists over the last two centuries, or the malignant things that have happened when youth-worship was mobilized by despots such as Mussolini or Hitler, persuaded the multitudes to reject the deep, distinctively modern conviction that individual and collective salvation from civilization's discontents lies in a recapture of childlikeness, simplicity, and "primitive" states of mind and spirit.

In a very common therapeutic scenario inspired by such notions, young people or "young" societies (pre-modern ones, that is) are designated as reservoirs of raw exuberance that can be tapped to revive a flagging, winded individual or class or nation or epoch. (Native Americans, for instance, were so designated by the 196os' counter-culture.) The old sometime seek to acquire the aura of the adored young by imitating their erratic enthusiasms, eccentric mannerisms, costumes or tastes; the encouragement of such imitation, as we shall see, was a programme of early Italian fascism. Or much more commonly, especially in bourgeois societies (since mimicry of 
the young by the old usually looks pathetic and absurd), they go about connecting with "youth" by acquiring artistic expressions or evidence of "youthfulness". Hence the centuries-old, never-ending European and North American traffic in artifacts made by "natives" in the colonies and by "folk" or "naïve" or "exotic" or untrained artists in the metropolitan homelands of capitalism.

Clearly, giving an adequate account of a single element in this pervasive modern fixation on immaturity - its effect on film, for example, or on painting or on psychiatry-would require a book several times the size of this essay. The carefully focused, critical monograph on imagery and metaphor and the uses of power in a specific time and place can, however, offer an inviting route into this dauntingly large territory. And indeed, in the case of fascist Italy's cult of young people, we have such an essay in English: art historian Laura Malvano's "The Myth of Youth in Images: Italian Fascism", published in $1997 .{ }^{\mathrm{I}}$

Illustrating her argument with regime-approved images and texts created in Italy between 1922 and 1945, Malvano shows the pervasiveness of anti-modernist primitivism's ideas about "youth" in fascism's representation of itself. The Italian people, she notes, are insistently portrayed in the media as a "young nation, with an aggressive and prolific vitality". ${ }^{2}$ The fascist establishment is the "vigorous heir to the fascist revolution, itself 'young and fresh". It is a "young", "innovative" state and, in the Duce's words, one "in full possession of all its energies [...]". ${ }^{3}$ In fascist society, even the civil servant would cease to be the flabby, servile functionary he had been in the hated pre-fascist times, and would (in the words of Ugo Cuesta, writing in 1934) "incarnate 'the plenitude of youth, the will to act, speed, and dynamism"”.4

Mussolini was fascist propaganda's epitome of everything the "new man" was supposed to be. "The eternal youth of fascism", Malvano writes, "had to be inseparable from that of the leader. The image of Il Duce therefore had to reflect all the attributes that the 'springtime of beauty' could bring to fascism: dynamism, strength, enthusiasm, efficiency, physical superiority, and a bold, combative spirit". 5 Thus was he presented, again

I. In G. Levi and J. C. Schmitt (eds), A History of Young People in the West, vol. 2: Stormy Evolution to Modern Times, trans. Carol Volk, London and Cambridge, Mass., Belknap Press of Harvard University, I997, pp. $232-56$.

2. Ibid., p. 246.

3. Ibid., p. 233.

4. Ibid., pp. 240-I.

5. Ibid., p. 250. 
and again, in posters, news photos, films, narratives, paintings and sculptures produced by servants of fascist power.

The goal was to generate a total media environment that reinforced the regime's association of itself with "youth", as that word was understood by anti-modern Europeans coming out of the cultural climate of the late nineteenth century and the trenches of the First World War. "The eternal youth, then, of an eternally young nation", writes Malvano, "translates into the political choice of a regime that makes youth the touchstone of its activities, the key to its own organizational system." ${ }^{6}$

She shows that the formulation of an iconography of "youth" in Italian visual propaganda resulted in two renderings of the theme, one earlier, the other later, both rooted in post-Enlightenment ideology about children and adolescent boys.

The earlier version (belonging mostly to the 1920s) — the one that concerns me most in this essay-celebrated the savagery, fearlessness and inclination to violence that a certain kind of Western primitivism has long attributed to boys. To promote this constellation of ideas as a new ideal, the fascist propaganda machine churned out images of youths that, Malvano says, recalled "the mythical 'sons of the wolf', the vigorous twins breast-fed by the she-wolf of Rome, the emblem of the Roman origins of fascism". 7

Along with wholly mythic Romulus and Remus, the regime exalted the name and fame of the semi-legendary Genoese boy nicknamed Balilla, who, in 1746, sparked a revolt of the Italians against Austrian occupiers by hurling a rock at an enemy officer. The fascist youth wing known as Opera Nazionale "Balilla" was founded in I926. "As for the Balilla" Malvano notes, "their slightly subversive founding myth made them a generation of bold, reckless, resolute, and courageous kids... ready to 'love risk and dare anything'." 8

The historical figures behind the "revolutionary" attitudinizing encouraged among boys by the authorities early on, of course, were the real revolutionaries of 1922 . While the "energy" and "ruthlessness" and so on of these young men were cultishly lauded in the enormous youth press, there was obviously no place in the new authoritarian order for their antiestablishment antics. Malvano writes: "The young madcaps who sang 
Giovinezza and casually handled bombs and daggers would find themselves institutionalized by the military ritual of the regime, becoming the Young Fascists who, by virtue of the Duce's decree, 'had to faithfully and silently serve in positions of obedience before being able to command'." 9 As fascism consolidated its leading position in Italian society, a new, still valiant but more politically docile representation of male youth was called for; and, once again, the fascist propagandists reached into the history of youth obsession, and came up with a usable prototype: "the classical image of the vigorous, athletic "ephebe". ${ }^{\text {Io }}$

By 1932, the venues of "high" art, such as that year's Exhibition of the Fascist Revolution in Rome, as well as the mass youth media were being populated by images of fascism's new male ideal. The youth press, particularly, "assumed a clear didactic function and glorified athleticism, the special symbol of values dear to fascism: the exaltation of physical activity, self-discipline, the virtues of effort, and the importance of teamwork (for which soccer was a powerful model)" ${ }^{\text {II }}$ Certain characteristics of the older tough-boy imagery persisted: the anti-intellectualism, for example, and the emphasis on "vitality", "energy" and so on. But in the ephebe, these presumably ancient traits, possessed by rugged early Roman men before the bourgeois, urban rot set in, were expressed as tame, channeled... militarized. By means of the new onslaught of elite-approved imagery, which swept through both the ateliers of high art and the offices of popular youth newspapers, fascism was preparing Italy's adolescent boys for recruitment into the mass armies of industrial-scale warfare.

While reading Malvano's interesting text about Italian art in the I920s and I930s, I began to think about another (so far unwritten) art-historical article, similarly dealing with the political economy of the image of "youth", the "primitive" and adjacent ideas, but in a setting that, on the face of it, seems very remote from fascist Italy: the New York art world around 1980, the birth-year of the so-called "Reagan revolution". The episode I have in mind has attracted the attention of numerous commentators-fans, foes, ideologues both pro and con, journalists and some serious evaluative critics. A few have noticed the frequency with which descriptions of the artists as "wild boys", les enfants terribles, and so forth cropped up in reporting and criticism at the time. None, however, has situated and explained the phenomenon, with anything like the suggestiveness of

\footnotetext{
9. Ibid., p. 233.

Io. Ibid., p. 234.

II. Ibid., p. 24I.
} 
Malvano's essay on fascist culture, as the thing I believe (and hope to show) it was: a manifestation of the perennial Western cult of immaturity.

Because nobody (to my knowledge) had written the essay I now wanted to read, I started to consider what it might look like, what avenues of inquiry its author might travel down, and so on. Here, then, is the gist of the chapter I had in mind.

This imaginary work of scholarship, employing the iconographic strategy Malvano used in her published text, would address the relationship of art and power in the moment when, very suddenly, new and wealthy collectors ignited a frenzied, short-lived market for paintings by young, male and frequently black New Yorkers dubbed "urban primitives", "wild boys", even "wolf children" by the art and popular media. ${ }^{12}$

The project would not, of course, claim that Mussolini's Italy in the twenties and Ronald Reagan's New York in the eighties were identical. It would acknowledge the profound historical differences that separate early Italian fascism and emerging American neo-liberalism- the fanatical nationalism that informed the former, for instance, versus the creed of individual selfishness that characterized the latter. It would distinguish the objects of primitivist desire in each circumstance: the angry young Italian men whose sensibilities were formed on the battlefield of the First World War versus the angry young American men who came of age in decaying east-coast cities in a time in American history, the years after the U.S. military misadventure in Vietnam ended, that was widely considered to be a decadent, rudderless end-of-empire episode.

Such a study might, however, discuss the primitivism that cultural trendsetters set to work in neoliberal New York as a phenomenon broadly continuous (as I believe it to be) with recurring Western primitivism, hence with the similar cluster of idea promoted by the fascist cultural leadership in Italy 50 years before. It might also point out the taste for "radical" anti-bourgeois art that has often prevailed (for a while) among young Euro-American elites newly elevated to power by rapid social and cultural change-whether in Russia after 1917, in Italy after 1922, or in New York during the anti-liberal "Reagan revolution" of the early I980s.

As we turn from Italy to New York, I would like the reader to bear in mind a specific image from fascist Italy's cult of youth: not the sleekly muscled ephebe of later fascist imagination, but the brash, passionate, bare-knuckled street kid, whose general type we will encounter again later on.

I2. I have seen all these terms in reviews. 
Three forces drove New York's incandescent art market in and shortly after 1980. The first was the passion for painting among key members of the new, nouveau-riche consuming class created in New York by market deregulation and other neoliberal economic reforms. According to the usual art-historical narrative of this era-something of a caricature, but I'm not going to challenge it now-the abrupt upsurge of hunger among new buyers for collectible, expressive, figurative painting in the early I980s was a result of the aesthetic drought that had turned the I970s into a dust bowl of drily intellectual, leftist, theory-driven Minimal and Conceptual art.

Be that as it may, these collectors would have had nothing to buy, of course, had it not been for a second force at play: the late-I97os rebellion of a considerable number of young New York artists against the late artistic modernism recently incarnated in Minimalism and Conceptualism. They were painting again, and painting figuratively, but with wide gestures not seen in New York since Abstract Expressionism. And they were rummaging for visual ideas in such hitherto unrespectable painterly sources as German Expressionism and the late De Chirico, and in the same attics that the Pop artists, such as Andy Warhol, had plundered 25 years before, especially American pulp media from comic books to TV sit-coms. A few of these young, exuberant painters-especially Jean-Michel Basquiat-had great talent coupled with promiscuous, Picasso-like curiosity about everything in the trove of imagery, from high modernist figurative painting (especially Picasso) to advertising and cartoons. The most important factor in their adoption by the new collectors, however, was their reputation for being "primitives"-poor, illiterate, but immensely creative street punks immersed in a hard-living, hard-partying existence on Manhattan's shabby Lower East Side.

The making and maintenance of this partially fictitious renown was performed by the third of my three influences: a cohort of stylish, sycophantic, anti-academic critics who were bewitched by the anti-intellectualism and "energy" of the young painters, and who were ready to flatter the tastes of the new collectors. Indeed, no element in this image-making machinery was more important than the New York art press, notably the radically overhauled Artforum magazine. For a generation, Artforum had been Manhattan's most reliable advocate of mainstream American modernism and outlet for staid, judicious criticism of it. In 1980, editor Ingrid Sischy changed the magazine into a pulse-taking document of current fashion, film, mass media, club culture and crazes, and especially the new painting activity. 
Artforum and other publications forged the mythology of the new painter as a raw, innocent child of Nature, a Balilla-like valiant boy, an impudent, downtown street-punk thumbing his nose at the art and the art-marketing apparatus of post-war cultural modernism. Because they were innumerable, I cannot here record every appearance of primitivist metaphor I have seen in the art criticism, catalogue essays, profiles, features, and documentary and fiction films that were rushed into production to heroize and glamourize this "new painter". But it is possible to convey at least a general sense of this imagery's application to the work and career of one New York artist: Basquiat.

Born in 1960 in Brooklyn to comfortably middle-class Haitian and Puerto Rican parents, Basquiat dropped out of school in his mid-teens, left home and, by around 1980, was living on the streets and treating himself to the hectic, drug-fuelled pleasures of the punk dance-club and art scene that flourished on Manhattan's grubby, desolate Lower East Side. Basquiat never had formal art lessons, but he was a gifted expressionist painter at a time when the new vogue for collectible pictures was galvanizing the art market. Unpredictable, beautiful, prodigiously energetic, fiercely talented, and-perhaps as important as anything else-black, very young and indigent in a city of well-off white artists and wealthy white collectors, Basquiat was quickly initiated into the churn of New York celebrity and instant stardom-and, at the same time, into the history of Western fascination with the child and the child's near relative, "the primitive".

The best short summary of this double initiation I have found is the unpublished (but easily accessible) study entitled "Artforum, Basquiat, and the I980s" by the American art historian Cynthia A. Gadsden. ${ }^{13}$ While Gadsden does not locate her discussion in the broad context of Western primitivist concerns - the thing I would like to see-her long essay usefully surveys Artforum's coverage of Basquiat and analyzes how this critical attention shaped the popular image and market reception of the artist. It is, in other words, a handy overview of the evidence for the spinning of a primitivist myth of the painter as wild child.

Viewed strictly from the standpoint of his commercial viability, Gadsden observes, Basquiat was ideally suited for absorption into the frenzied New York painting market of the early i980s.

13. The text is a 2008 master's degree thesis submitted to the College of Fine Arts, Ohio University. It is on line at <http://etd.ohiolink.edu/send-pdf.cgi/Gadsden\%20Cynthia\%20A.pdf?acc_num=ohiour217965257>. 
In such an image conscious, pop culture decade — she writes- his youth, energy, personality, and mixed racial heritage was an easy choice. The combination was ideal for enticing art collectors and investors to the sagging art market. He proved marketable across racial, national, and financial boundaries, and every aspect of the art marketplace used him and his image to their economic advantage. ${ }^{\mathrm{I}}$

Even Basquiat's lack of formal training added to his commodity gleam.

He was an outsider with personal experience with the street. He challenged established rules with a style that embraced the look of the primitive, untrained artist. He was as comfortable painting crude drawings interspersed with hand lettered block letters on a concrete wall as on a gallery canvas. ${ }^{\text {Is }}$

As these observations suggest, the readying of Basquiat for art-world and popular celebrity went hand in hand with a more fundamental transfiguration from just another very gifted artist into the wild boy of Western imagination. The rhapsodic tone of all subsequent Basquiat-worship, and the complimentary association of the artist with the "primitive", l'art brut, and even the Divine Baby of Western myth and piety, was established in 198I, when the first important article about him, Rene Ricard's "The Radiant Child", appeared in Artforum. ${ }^{16}$ "If Cy Twombly and Jean Dubuffet had a baby and gave it up for adoption", Ricard wrote, "it would be Jean-Michel." Wise, hardened by the streets, but still blessed with inextinguishable naïveté, crude in manner but divinely inspired-this offspring of Dubuffet was all these things, according to Ricard and other critics. And, indeed, Gadsden's close reading of his critical reception leads her to conclude that "the art writing in Artforum was instrumental in creating an image of Basquiat as a brilliant, creative primitive. This characterization and his mixed racial heritage coincided with lingering Western art imperialist beliefs about the exotic Other". ${ }^{17}$

Always ready to exploit the spell he cast over collectors, critics and other art-world powers, Basquiat apparently welcomed this stereotyping, even after it became a hackneyed feature of virtually everything laudatory written about him. "Characterizations of Basquiat as savage and wild dogged him throughout his career", Gadsden found. "Clearly art writers for magazines such as Artforum, Flash Art, and Art International, and their readers continued to desire the modernist primitive in the form of the young, 'feral' painter who happened to be other than white." ${ }^{18}$

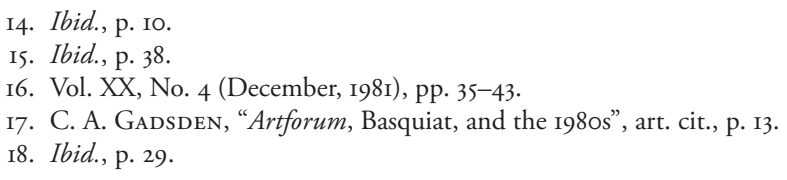


In addition to fervent admirers, Basquiat, and the painting explosion in which he was the most prominent figure, always had enemies-especially among critics who had made their careers defending the more stringent and often overtly political Minimal and Conceptual practices of the I960s and I970s. But some writers who were devoted to his art feared that the greater danger to its long-term standing came from its fans. In a 1982 review, critic Jeffrey Deitch issued this caution: "Basquiat is likened to the wild boy raised by wolves [...]. A child of the streets gawked at by the intelligentsia. But Basquiat is hardly a primitive. He's more like a rock star, seemingly savage but completely in control [...]." ${ }^{\text {19 }}$

The warnings of Deitch and other sympathetic commentators did little to squelch the wild-child myth, endlessly reinforced in the media, that always made the dispassionate critical evaluation of Basquiat's painting difficult. And, indeed, throughout the artist's short career-ended by a heroin overdose in 1988, when he was just 27-and ever since, his genuinely remarkable accomplishment in painting has been overshadowed by the farrago of gossip, legend, lurid biographical anecdotes and mythology that his publicists put about (usually with his collusion) during his brief transit among the media-made American art stars of the $1980 .^{20}$

A great deal of interpretative work remains to be done, if the art-historical record of what Basquiat actually did is to be set straight. And an iconographic study of the kind I am proposing here could also help to dispel the fog of misinformation and partisan name-calling that still hovers around his figure. Any such project would obviously have to set forth, as Laura Malvano has set forth, an accurate account of the primitivist "story" demanded by the elite consumers of culture and fabricated for them (and, of course, the public) by critics, popular journalists, filmmakers, biographers and others. But again following Malvano's example in the essay I have discussed here, a researcher into this topic would need to identify the political and social agenda behind the particular fluorescence of elite cultural primitivism under investigation. Outbreaks of primitivist fantasy in Western civilization, after all, never come from nowhere.

In his or her attempts to nail down this agenda, there is a lot of territory the researcher would not have to investigate anew. The culture of greed,

19. In Flash Art, May 1982, 49. Quoted in Ph. Hoban, Basquiat: A Quick Killing in Art, New York, Penguin Books, 2004, p. IIo.

20. Neither Julian Schnabel's widely acclaimed 1996 film Basquiat nor Phoebe Hoban's breezy, gossipy 1998 biography give us any reasons to appreciate the artist's work; both merely perpetuate the myth of the Genius Child. 
fabulous consumer excess and self-congratulating wealth that became conspicuous in the United States, and especially in New York, during the I980s, for example, has been extensively studied and documented, and its roots in Reagan-era neoliberalism are well-known. Similarly wellunderstood are the images of themselves projected by the New Yorkers who created the art market of the early I980s, and by their admirers: We have the countless profiles, news stories, documentaries, films and novels that breathlessly described them as "masters of the universe", "revolutionaries" embodying "dynamism, strength, enthusiasm, efficiency, physical superiority, and a bold, combative spirit". (My citation of Malvano's list of the virtues attributed by fascist propaganda to Mussolini is deliberate. Avant-garde ideals of maleness have changed very little over the career of cultural modernity.)

But it could be interesting to try deducing their political and social ideas simply from what the collectors bought during the frantically overheated art boom that coincided with the financial boom of the I980s. Imitating Laura Malvano's skillful handling of the visual evidence available to her, one would probably find, for instance, that the "new men" of the I980s (like the "new men" in Italy during the 1920s) — though in fact radically anti-liberal, hierarchical and basically authoritarian-wanted paintings that flattered their sense of themselves as formidable youths, street-wise, sceptical toward traditional authority, impudent, and, of course, "energetic". Nourished by the extreme individualism and glorification of selfishness and hedonism endemic in neoliberal social and political culture, they bought art that was as boisterous and sensual and chthonic as they believed themselves to be-art by artists they could view (by squinting a bit) as revolutionaries and "outsiders" like themselves. At least for buyers (i.e., most of them) who weren't looking very closely-who swallowed the primitivist hype of the promoters hook, line and sinker-the young painters could seem like counterparts, members of a vanguard defiantly opposed (like the buyers) to the traditional humanistic values (and art) of post-war welfare-state society. The myth of boys raised by wolves had reappeared in Manhattan by the early I980s, aligned, as usual, with a more general right-wing programme of cultural and political "rejuvenation".

Some new painters, it should be said, resisted this appropriation. Basquiat, the most promising of them all, did not, and readily indulged his patrons' primitivist fantasies of him as a latter-day, art-world Balilla. For a while, this self-presentation worked to his advantage. He finally destroyed himself in 1988 , however, after a quick transformation by the 
celebrity process into the louche, materialistic, on-the-make "bad" childdrug-addicted, incompetent-that American child stars often become.

But by the time he died, the romance of the neoliberal art-fan elite with wildness was already over, and the collectors whose shiny new millions had fuelled the boom market in neo-expressionist American painting a few years before were ready for a rappel à l'ordre. In a move that echoed Italian fascism's image-switch from wild boys to classical athletes in the early I930s, most of the trend-setting collectors, and their acolytes among the critics and curators, abandoned the painters and became patrons of mainly uncontroversial, academically proper, intellectually respectable (but also highly collectible) neo-Conceptual photography, sculpture and installation art. Unlike the steamily expressive painting that had caught their fancy around 1980, this newer art was cool, sophisticated, emotionally detached-something definitely made by and for responsible, educated grownups. Another page had been turned in the unfinished (and perhaps unfinishable) annals of the Western mind's deeply problematic hankering for primordial freshness, vitality, youth. 